\title{
BUILDING CHARACTER OF HARDINESS THROUGH RELIGIOUSITY AND LOCAL WISDOM FOR MERCHANT MARINE CADET IN ACEH, INDONESIA
}

\author{
Subiyantoro', Mangun Budiyanto2 ${ }^{2}$ Budi Riyanto 3 , Buyung Surahman ${ }^{4}$ \\ 1,2.Universitas Islam Negeri Sunan Kalijaga, Yogyakarta, Indonesia \\ 3Politeknik Pelayaran Malahayati, Aceh, Indonesia \\ ${ }^{4}$ IAIN Bengkulu, Bengkulu, Indonesia \\ *subiyantorodr@gmail.com
}

\begin{tabular}{l}
\hline Article Info \\
\hline Article history \\
Received June 11, 2021 \\
Revised August 8, 2021 \\
Accepted August 13, 2021 \\
\hline \\
Keywords: Hardiness \\
Character; Religiosity; Local \\
Wisdom; Merchant Marine \\
Cadet.
\end{tabular}

Cadet.

\begin{abstract}
This study describes the character-building model of prospective marine transportation cadets in Malahayati Merchant Marine Polytechnic, Aceh, Indonesia. The research method in this study was a qualitative phenomenological research design. The data was found through participatory action research, in-depth interviews, observation, and documentation, which Miles and Huberman's model used as data analysis. The data analysis process consisted of data reduction, data display, drawing conclusion/verification. The research result showed that character educational implementation of Merchant Marine Education in Aceh has been conducting through (1) the instruction method, education, suggestion, persuasion, trusting, punishment, guidance and counseling, habituation, group discussion, and organizational activities. The method implementation adjusted to the activities and educational cadet level starting from prospective cadet to senior cadet. (2) Method implementation intervention conducted through the hidden curriculum like moral knowing, moral feeling, moral action, and religiosity manifest in five diversity dimensions: religious belief, religious practice, religious feeling, religious knowledge, and religious effects. (3) Attitude nurture implementation conducted through local wisdom habituation includes exemplary leaders/coach/trainers/senior cadets, behavioral standards, and reflection studies. (4) Religious character educational implementation bears a resilient cadet profile who is intelligent, professional, skilled, and sound. This research finding recommended the importance of religiosity and local wisdom in building the character of Hardiness.
\end{abstract}

\section{INTRODUCTION}

Tragic incidents that led to the death of students occur in boarding-based official education institutions in Indonesia often. The student's death was caused by acts of violence committed by senior students against junior students. Several cases of death, for example, occurred in the boarding institution system, such as the death of Taruna Nusantara secondary school student whose name is Krisna Wahyu; he died pathetically in the student barracks. He died with a stab wound to the neck, which the culprit was AMR as his colleague (Doc. 
JawaPos.com, Tuesday, May 2, 2017). The death of Higher Education Maritime Institute Jakarta students, Amirulloh Adityas Putra (18 y.o.), and Higher Education Maritime Institute Marunda, Cilincing, North Jakarta were caused by violence committed by senior students in 2017 (Doc. JawaPos.com, May 2, 2017). The student of the Islamic boarding school in Tanah Datar district died after being mistreated by several students for three days in NI Islamic Boarding School in Nagari Balai Gadang Koto Laweh, Tanah Datar district (Doc. Tribun.com). The death of a cadet in Makassar Aviation Safety Engineering Academy was caused by a persecution case resulting in Aldama Putra's died after being persecuted by his senior student in 2019 (Doc. Tribun.com). According to plenty of cases that caused many students to die, it seems that young age, where people are still searching for their identity, also affects the student emotion to interact between senior and junior students.

Referring to Hurlock's statement, adolescence is windstorm, tidal and low storms uncertainly, like a firecracker whose axis can automatically ignite, exploding at any time (Farida, 2014). The development of psychology in adolescents is very significant. Their critical nature begins to develop, and they do not want to immediately comply with the advice or prohibitions directed at them (Farida, 2014). Therefore, calamity commonly happened in boarding schools. Developing individual character, commonly called mental training, sometimes causes tragic incidents in several educational institutions, like persecution to cause death. This incident seems to be inseparable from an empty soul and stress.

Violence in the school, fights between students, disrespect, lack of manners, and intimidation have grown and developed in daily life and are shown through mass media worldwide (Hariyanti \& Sudjito, 2018). Therefore, due to globalization, character building in Indonesia needs to be seriously taken (Safitri, 2018). Character is somehow grown in the long term and naturally sticks to someone's life (Tiwari, 2020).

Young nation generations need to prepare the hardiness character to encounter future life. Hardiness is a detected human quality under challenging situations, challenges, and difficulties requiring mobilization of individual vitality and personal resources to overcome terrible living circumstances. Maddi and Khoshaba (1994) defined Hardiness as an integral feature in responsible individuals overcoming life difficulties (Zeer et al. 2016). From several kinds of research, this turbulent youth factor has become one of the causes of student relations deterioration.

The phenomenon of violent action between senior students and junior students in the boarding-based official school is not found in the educational process in Sekolah Taruna Pelayaran of Aceh, Indonesia (Aceh Merchant Marine Cadet School). Merchant Marine education of Aceh has a different education system, whereby this institution performs its educational peculiarities. The educational model of Malahayati Merchant Marine Polytechnic applies local wisdom to build trustworthiness and Hardiness. The indicators of character building which distinguish other transportation education describe as follows: (1) 
mentioning/calling senior or junior cadet in Aceh (as mentioned in other Merchant Marine Polytechnic as well) with "Abang" or "Adik"; (2) applying local wisdom in the relation with God (Habluminallah) and the relation among the humans (Habluminannas) and carrying out Friday prayer (a congregational prayer (salat) that Muslims hold every Friday, just after noon in dhuhr) and Eid prayer together with the society outside the college; (3) carrying out the ceremonial event that involves other religious community, or the guests whose religion is not Islam, while still respecting each other by upholding Islamic identity; (4) holding two words that are permanently attached to the cadets and their coaches "asking for permission" and "ready." The two words with "deep meaning" characterize the social relationships in the boarding of Merchant Marine education in Aceh. In line with Kovacs \& Borcsa's research, this education for cadets in Aceh also forms a robust personality to encounter stressful and anxious conditions (Kovács \& Borcsa, 2017).

According to the description above, Aceh Merchant Marine Education has its peculiarities regarding its location. This province implements Islamic teaching and the life that sticks to religiosity, leading to no prominent violent actions (interview, 2018). Therefore, it is exciting and worthy to be a research subject and object that aims to find how the character education model forms the cadets to have social, religious, and Hardiness built. This study describes the character education model of prospective transportation cadets in Aceh Merchant Marine Polytechnic, Indonesia.

\section{METHODS}

This research type is qualitative-naturalistic research. This research approach is phenomenology-oriented research, observing the symptoms by focusing on the application from the perspective under study and what the research subject has experienced. The research construct comes from the subjective symptom (phenomenology) experienced by the research subject. This research focuses on forming religious character and characterbuilding individual personality through resocialization related to the socio-religious study.

Data collection has used Participatory Action Research, an in-depth interview of trusted interviewees, observing the education process, and documentation. Data presented by descriptive narration through the analysis process of documentation results, in-depth interviews, and observation in the research field. The data validity test used the triangulation technique, source triangulation, and time triangulation also conducted observation extension.

Data analysis used the Miles and Huberman model, in which the process of data analysis consisted of data reduction, data display, and conclusion/verification. The source of documentation data was prospective transportation management cadet education of the main level, observer participants of character educational management in Aceh Merchant Marine Education, and stakeholders Aceh Merchant Marine Education. 


\section{RESULTS AND DISCUSSION}

Based on the analysis data, four essential themes are also the answer to research problem formulation.

\subsection{Character Educational Paradigm on Socio-Religious Perspective in Aceh Merchant Marine Cadet Education}

The Law of Republic Indonesia Number 20 of 2003 about National Education System underlines Aceh Merchant Marine Cadets' character education. The Law serves to formaljuridic foundation and reference of educational implementation standard nationally, also aims to develop student's potential in order to be a human who fear and believe in the one and only God, having a noble personality, healthy, knowledgable, competent, creative, independent, and being a democratic and responsible citizen. In the Law of Republic Indonesia Number 20 Article 3 of 2003 about National Education System, nation generation can harmonize thought (olah pikir), soul (olah hati), body (Olah raga) to manifest fearful behavior towards Allah SWT, humanist, pluralist, and democratic (Wardoyo, 2015).

The implementation of caregiving and character education of Aceh's Cadet uses Cadet education guidance, Ministry of Transportation of Republic Indonesia and Jakarta Human Resource Development on Transportation Agency of 2018, also the regulation of the chief of Human Resource Development on Transportation Agency Number PK 2/BSDMP-2018, also in the field referring particularly to Cadet Regiment Integrity Pact of 2nd-period in batch VI Poltekpel Aceh of 2019.

According to Ichsan, character maturity always relates to someone's experience facing condition rotation that always experiences the changes and developments (Ichsan, 2011). It indicates the implementation of character education and cannot separate from the social entity. The abovementioned research argumentation supported by Garry Martin dan Joseph Pear's statement stated that human behavior tends to be influenced by conditioned reinforcers that come from outside human self (Martin \& Pear, 2015). Within the scope of social entities, human needs soft skills in life success.

The statement of the importance of soft skill competence is in line with the research result of Harvard University; human success is not determined by knowledge and complex skill but mainly determined by self-management and other people's involvement (soft skill). Human success is determined by soft skills (about 80\%), while complex skill is only $20 \%$ (Wibowo \& Purnama, 2013).

This research result is in line with the research of Viola et al., the necessary implication of research finding related to the intervention of career counseling increase a positive personal human resource ability, behavioral skill, psychologic, and mental that are needed to strengthen hardiness skill, like the ability to solve problem and interaction supported a practical social life (Viola et al., 2016). 
Efimova et al. (2019) stated that rapid changes characterize modern civilization, increased social life demands like the adaptation to surrounding society. The hardiness concept closes to the meaning and someone's potential characteristic in facing difficult life situations. Hardiness means can act as substantial internal resources to overcome stress; at the same time, Hardiness is the component system, a combination that forms potential personal features. The interview result by the chief of administration and also a lecturer in Poltekpel Aceh is stated below.

"Education in Malahayati Merchant Marine Polytechnic, Aceh, is different from other institutions due to the different environment. Acehnese society is living dominantly under the Islamic Religion." I feel this way because we have also served in other Merchant Marine Education in Semarang and Medan, besides frequently visiting other Merchant Marine Education. Character education of Hardiness is also specially held by the unit and competently educated staff in their field formed to tackle character education. They plan, implement, coordinate, and initiate character education to evaluate boarding lifelike soft skills in this institution. Character education is built through a religious approach, which local wisdom of Acehnese society is social control (Interview, November 2018).

Aceh Merchant Marine Cadets' soft skill competency formation is carried out through embedded and stand-alone method activities. Embedded activities are carried out according to main daily activities in 24 hours. At the same time, stand-alone method activities are carried out through specific activities that aim to increase or instill specific soft skills.

Embedded soft skill competency and stand-alone method activities are expected to achieve seven competencies of the cadets. First, Integrity; act and behave professionally, honestly, and obediently. The second, Good Work ethics without supervision dan responsibility. Third, Initiation (Pedoman Pola Pengasuhan Taruna, 2018). Fourth, constructive and effective communication. Fifth, cooperation. Sixth, Interpersonal relations. Seventh, Adaptation and Hardiness for adjustments to changing conditions (Pedoman Pola Pengasuhan Taruna, 2018). Implementing religious values in this character education is carried out through a hidden curriculum process (Hamdani \& Saebani, 2013).

\subsection{Religiosity as Student Character Formation}

From the viewpoint of the society, social perspective and religiosity use the paradigm of Glock and Stark theory that stated if religiosity consists of five elements of the religiosity: religious belief, religious practice, religious feeling, religious knowledge, dan religious effects (Glock \& Stark, 1970). Five dimensions will also be described: first, the Ideological aspect (the aspect of faith, belief, and the relation between humans and God). The second is the ritualistic aspect (the aspect of worship, frequency-related aspect, and intensity of worship implementation). The third is the significant aspect (charity aspect and behavior in life). Fourth, the Experiential aspect (kindness aspect related to experience and belief about the existence 
of God). Fifth, the Intellectual aspect (knowledge aspect related to religious teaching) (Sutipyo \& Latifah, 2016).

The education method is included in several ways. Instructive, the method to instruct the cadets to know, understand, carry out, and prohibit some action in increasing discipline, skill, ability, and balanced cleverness. Educative is the method to educate, enhance and raise motivation by involving an active cadet in teaching-learning implementation. Suggestive is the method to encourage and motivate in view, advice, or communicative feedback. Persuasive, a method to conduct a constructive and positive action. Belief is the method to obey the rule and carry out the task without supervision and coercion to foster self-confidence and independence (Pedoman Pola Pengasuhan Taruna, 2018). Sanctions, the method of giving appreciation/praise or punishment/warning. Guidance and counseling, the method of giving help in the form of instruction or guidance. Thus, habituation, the method to behave according to set rules. Group discussion and organizational activity, organizing activities outside extracurricular activities to introduce organizational life (Pedoman Pola Pengasuhan Taruna, 2018). The eleven abovementioned methods are packaged in boarding life activities 24 hours by applying ethical or behavioral standards.

The analysis of the relation between religiosity theory and education method that is implemented to Aceh Merchant Marine Education and can be explained as follows:

- Ideology/Akidah/Faith's dimension is manifested in the belief to increase cadets' consciousness to carry out worship without coercion and a human factor, but it is due to Allah SWT.

- The dimension of ritual is manifested in the Instructive and Habituation method. Worship is included in every religion that covers orders and routine activities. Furthermore, daily activity implication outside the Ritual of Religion is based on religious rules/norms and habituation.

- Consequence/religious impact is manifested in giving sanctions, either achievement/kindness or punishment/offense. It is related to Sunnatullah (The Immutable Constants of Allah's System). Every aspect of the action will affect by the process.

- The dimension of Experiential is manifested in an educative, suggestive, and persuasive method. Experiential is the experience of religiosity. People in their daily activities also cannot be separated from their previous experience of the activities.

- The dimension of intellectual or knowledge is manifested in educative, guidance and counseling, and group discussion. Knowledge is obtained from the previously mentioned methods, in which the knowledge is to be implemented in the whole life aspects.

Five religiosity dimensions are manifested in the methods implemented in the educational process with behaviors that have been standardized as well so that the target and educational way are clear.

Behavior ethic standard is also regulated in cadet education guidelines. This behavior that has been regulated includes daily activities, such as how to call, walk, sit, visit, attend the invitation, and others. A demanding behavior standard with many implementation methods is to form students' character of noble and Hardiness. This argument is in line with Naqvi's research

IJEMI Vol.2, No.3, September 2021, pp. 330 345 
that education goals are to produce virtuous citizens. This phenomenon can be achieved by building the strong character of the students (Akhtar \& Saeed, 2021).

The observation result in Merchant Marine Education of Aceh showed that religious character was carried out by creating a positive education culture. This positive behavior is like respecting institutional leader, coach, caretaker, and writer (as a guest), loving junior students (junior cadets), being discipline to undergo every activity, being obedient and responsible to every command and task that are given, and also actively involving in every worship activities (Observation, September 9, 2017). Several indicators showed that religious values were embodied through educational institutions' culture, leading to achieved religious character in the character of discipline, hard work, and Hardiness.

The result of the observation showed that the activities could be seen from the aspects of religiosity. Faith can be observed when the cadets are doing worship activities or daily activities outside the worship activities. Regardless of the supervision, the cadets usually pray Shubuh in the mosque. It is encouraged by their faith or the dimension of Ideology stuck on themselves. This condition has integrated religious aspects and Aceh's local culture that the Acehnese society is indeed religious. Other activities are praying that led by the class administrator, also short scientific lecture that is usually carried out by one of the cadets, then followed by reciting Al-Qur'an, reading Hadits and the explanations, and sometimes conducting group discussion/sharing as well (observation, September 9-12, 2019).

Congregational prayer activities of the cadets without any supervision runs orderly, Istiqomah/sustainably, and sincerely. Some dimensions from that attitude include Akidah/Belief dimension that sticks on the heart then moves to the mind; moreover, it drives a body to carry out the activities. The Ritual dimension appears in praying and remembering Allah SWT (Dzikir) as routine activity practice; thus, the dimension of knowledge lies in scientific lectures. The Knowledge dimension seems weak due to the lack of religious knowledge obtained from the scientist of religiosity. The cadets experience the dimension of Experimental, while the dimension of Consequence is visible in the cadets' daily life activity impact. The whole activities lead to a strong self character so that it creates hardiness character as the individual personality that is physically and mentally healthy.

Serdiuk, in his research, said that Hardiness is holistic, open organized, and independent relation system determined by the individual and the world, and resources needed can be contributed to improving individual physical and mental health, also become a success in adapting the difficult life situation, choice, and personality transcendence (Serdiuk et al. 2019).

\subsection{Local Wisdom As The Modal of Social Control}

This implementation of the education for the cadets is seen according to the context of the local Achenes societies supported by a high level of religiosity, which is proven by the status of geopolitics in Nanggroe Aceh Darussalam (NAD), as the only autonomous regency in the 
territory of the Republic Indonesia (NKRI) that has predicted as "Porch of Mecca" (Indonesian: Serambi Mekkah) (Mukhlis, 2019).

The cadets' education level is Diploma 3, consisting of several educational levels: (1) Orientation Stage (within six months). The orientation process begins with the Basic Period for Forming the Character of Cadets (Madatukar) for two weeks, then continued with the Basic Period of Mental Development (Madabintal). (2) A forming Stage (within six months to 12 months) is called youth cadets (Taruna Remaja). (3) Maturity Stage (within six months to 18 months), this period is called Middle Cadets (Taruna Madya). Thus, (4) Maturation Stage (within six months to 12 months), this period is called Adult Cadet (Taruna Dewasa).

In every stage, technically, the caregiving activities are divided and distinguished according to the levels encompassing goal, method, actual practice operational, and supported operational of the caregiving. The methods are adjusted to caregiving stages (from four stages) using Instructive, educative, suggestive, habitation, sanction giving, guidance and counseling, persuasive, group discussion, trusting, and organizational activities, as explained in the analysis above, as thee methods. The process of character education using those various methods is related to physical and spiritual education.

The research of Zickriya asked whether the living things are separated into two entities, material soul and non-material soul, or only a fiction creature, related to the abovementioned explanations. Religion and eastern people beliefs believe in the dualistic human so that the two elements must be educated. However, most scientists and philosophers have different views about the monistic theology that stated that humans are the only substance. The interaction of soul and body is a complex phenomenon. It is the interaction between them, but it is different and is a separate entity (Khwaja \& PaiVernekar, 2018). This research result strengthens that these two entities are the type of educational entity that must be trained to open the opportunity, soul that must be educated with vivid character.

The observation result showed that the cadets are given the activities leading to physical and spiritual health to succeed together in life. These activities strengthen the basis of local wisdom along with social life. It is showed by the activities of the Basic Period of Mental Development (Madabintal).

The observation result stated that cadets were grouped into several groups and carried out the "Jungle Survival" activities. The cadets' initial activity gave different codes in each group to look for food materials hidden tightly in the shrubs. They must look for the food materials to cook together with the group and then lunch with other groups. In this activity, several groups quickly got the food materials, and others did not; they just found the food materials after hours. They also have to care for other groups whose food is not sufficient enough. Before other groups found their food materials, several groups could not eat their food because they cared for their peers. They must work hard and cooperate among the individuals and groups to solve difficult situations and form Hardiness. 
Reflection on what lessons could be learned from the "Jungle Survival" activity in the evening. It turned out that the cadets could analyze and discuss in detail the benefits of this character education. They conveyed their opinions reflecting on the activities carried out during the previous day. Thus, the critical way is how to implement these lessons into life together in a boarding.

The author also feels how they encountered difficult situations with hungry stomachs while the time to complete tasks was limited. Therefore, cooperation, hard work, innovative work, care for others, not living individually, physically, and mentally healthy, and creating a hardy character was needed. On the other hand, they also must obey the rules and respect the trainer. The local wisdom that has been built in the cadets' life is in line with the values of religiosity that every person must work hard, particularly in their field, willing to help each other, care for others, respect elders, and cherish to the younger. After two weeks of Basic Period for Forming the Character of Cadets (Madatukar), the cadets are taught the written stages above. The interview result with the manager of Malahayati Merchant Marine Education of Aceh describes as follows:

"The process of building the character in Malahayati Merchant Marine Education of Aceh was carried out by boarding system. In this institution, we provide an open opportunity to carry out the mental and personality formation process and also the opportunity to train physical and spiritual direction. It has been stated according to education standards by Human Resource Development on Transportation Agency, further adapted by Malahayati Merchant Marine Education of Aceh. For example, newly accepted junior cadets have to go through a process of isolation from the outside for three months (Interview with the leader of Malahayati Merchant Marine Education of Aceh on September 6, 2019).

In the boarding, the cadets are accustomed to scheduled activities from Monday to Thursday. On Friday, activities starting at 04.30 to 21.30 WIB. Cadet's cruise schedules are determined by Taruna's caretakers and held on Wednesdays from 15.30 to 21.00 WIB. On Thursday from 19.30 to 21.00, Spiritual activities of each religion are held. In addition, the daily activities of Taruna the cadets, on Saturdays and Sundays, are regulated and differentiated between Cadets who permit to stay overnight and those who do not.

Apart from the daily assembly, cruise assembly, permit assembly, extraordinary assembly, also breakfast-lunch and dinner assembly. Cadets who drive picket assignments must use the particular attribute or accessories. In its implementation, Picket activities consist of five activities: first, daily guard picket, picket activities in each platoon to maintain the platoon's activities. Second, porch guard picket, the picket for guarding porch (boarding) from 22.00 am to $06.00 \mathrm{pm}$. Third, the particular guard picket carries out guard duties to monitor security and supervise special events. Fourth, the room guard officer, picket to maintain neatness, security, and cleanliness in each room.

The research result showed that the religious character education process created character hardiness in Malahayati Merchant Marine Education of Aceh was carried out from 
creating and conditioning cadets' learning environment. It is showed from the interview of the manager as described below:

"In educating cadets, we considered the cadets in Malahayati Merchant Marine Polytechnic of Aceh sociologically. Also, the majority of cadets came from Nanggroe Aceh Darussalam, where known in their Islamic values, the values have adhered in Acehnese local wisdom that further becomes a modal in the social aspect by which we had developed in the educational process (Interview with Leader of cadets in Malahayati Merchant Marine Polytechnic of Aceh on September 6, 2019).

The conditioning process in character education is relevant to Yasin Nurfalah's statement that character-based education leads to instilling the habituation of the good things so that children's know-how is good and is not (cognitive domain). Also, they can assume the good values (affective domain) and is willing to do good things (psychomotor domain). In the research of Ping (2020), humans are responsible for setting a nature. Setting the nature is to set a nature and its elements that are needed the character of responsibility, Hardiness, etc., especially for prospective Merchant Marine Cadets. An Islamic perspective seems to be the best alternative in dealing with and helping nature heal from the (possible) corruption.

"In educating the cadets, we committed to implementing boarding-based education, implementing and using local wisdom and cultures attached. Because boardingbased education helped us monitor the students' activities within 24 hours orderly structured, it underlined their religious character education and local cultural wisdom. Implementing a boarding system is an attempt to adjust an educational environment suitable to cadet professionalism demand as the future prospective transportation cadets (Interview result of Character Building Center Organizer, Malahayati Merchant Marine Polytechnic on July 9, 2019).

According to the leader of Poltekpel of Aceh, religious character manifested in the local wisdom is the critical component that cadets must have to grow the consciousness inside cadets' self in order to perceive that a sailor is not merely a profession, but as a call of the soul based on sincerity to serve the nation and state, for the benefit of humankind. The following is an excerpt from the interview with the head of the institution.

"The boarding activities run structured. The trainers monitored the activities and carried them out directly in stages by a person in charge of the cadets' events to run orderly. Also, there was a measured sanction for cadets who broke the rules and were aware of them. This activity was oriented to the religious character and Aceh's local wisdom. The activities were built by rituals like praying five times together, sincerity, togetherness, and society's benefit (The interview result of the leader of Malahayati Merchant Marien Polytechnic of Aceh on July 9, 2019).

The implementation model of religious character education and local cultural wisdom in Merchant Marine Education of Aceh could be presented in the schemes below: 


\subsection{Educational Pattern of Aceh Merchant Marine Cadets}

Character educational patterns in Merchant Marine Education of Aceh can be presented in the scheme model as follows. The intervention is carried out through the hidden curriculum or religious education process, and local wisdom leads to the expected target and goal.

\section{Religious Character Educational Implementation Scheme in Malahavati Merchant Marine Polvtechnic of}

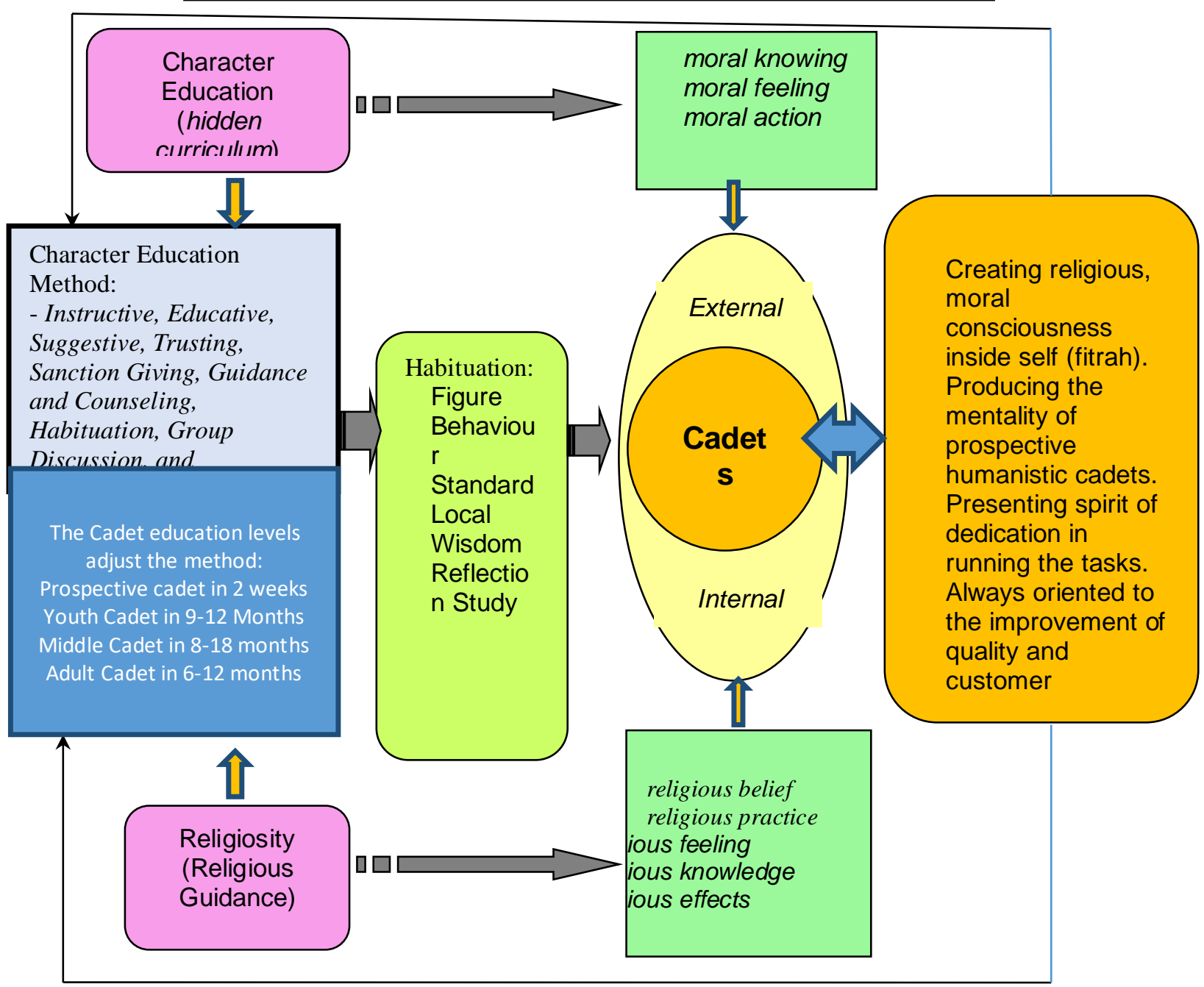

Figure 1. Religious Character Education Implementation Scheme in Malahayati Merchant Marine Polytechnic of Aceh

The scheme revealed that socio-religious character education in Malahayati Merchant Marine Polytechnic of Aceh is carried out through habituation, including four factors: figures, behavior standard, reflection study, and local wisdom approach.

Figure aspect tends to present a concrete example from good actions, which is expected to stimulate to do better things (The interview result of the leader of Malahayati Merchant Marien Polytechnic of Aceh on July 7, 2019). Cadet figure leads the cadets to imitate the leader, caregiver, trainer, and senior cadets (The observation result about the 
cadet interaction pattern in Malahayati Merchant Marien Polytechnic of Aceh on July 9, 2019). The behavior imitation process drives unconsciously through class learning activities, physical training, and the culture of educational institutions. For example, junior cadets call their senior by using the word "kakak."

"The leader, caregiver, and trainer here are always given a good example. They are consistent with the rules being agreed together. When class learning is conducted, we feel that physical training activities and the culture of educational institutions are built together. The culture of respecting the elder and cherish the younger has developed here. Several words adhered to our daily life are "ready" and "asking for a permit." The word "ready" showed that we were ready to carry out the task and obey the rules. The word "asking for a permit" showed the act of respecting others in terms of words and actions (The interview result of Senior Cadet of Malahayati Merchant Marine Polytechnic of Aceh on July 10, 2019).

The moral responsibility to be a cadet who exemplifies a good action for others is a point attached to Aceh Merchant Marine Education Cadets Regiment Staff (Cadet Regiment Integrity Pact Period 2 Batch VI of Malahayati Merchant Marine Polytechnic of Aceh of 2019). The use of behavioral standard as an aspect of the habituation process to support an achieved religious character education is a control point that will periodically evaluate the behavior development of cadets during the education/caregiving period (The interview result of Center Organizer of Character Building, Malahayati Merchant Marine Polytechnic of Aceh on July 9, 2019). The behavior standard has regulated all of the cadets' activities during the education and caregiving process. They are expected to have an orderly and disciplined character in carrying out their duties and responsibilities professionally. The interview result is provided in the following explanation.

"We have set the behavior standard. Furthermore, we formed a particular sub-section to monitor character education. The expected behavior has been packaged within 24 hours activity in the boarding like carrying out guard picket, conducting eating rule, dressing, praying together, shipping, and meeting to society while carrying out particular events" (The interview result of Malahayati Merchant Marine Polytechnic of Aceh on July 7, 2019).

The role of local wisdom in implementing religious character education in Malahayati Merchant Marine Polytechnic of Aceh relates to local Islamic values and is absorbed in educational institutions' culture. Terrence E. Deal dan Kent Peterson stated that tradition, ritual, and vivid local values developed in the school circumstances and powerfully impacted the appearance, way of thinking, action, and feeling (Deal \& Peterson, 1999)

The most formidable challenge in reflective studies is that the cadets can connect the social phenomenon they have experienced with the formal educational process taught material. The implementation of reflective studies is conducted through Sub Camp whereby they are trained to have high social sensitivity and limited distribution of food rations, for example, toward the cadets who get and do not (the observation result of Sub Camp in the environment of Malahayati Merchant Marine Polytechnic of Aceh on September 7, 2019). In

IJEMI Vol.2, No.3, September 2021, pp. 330 345 
addition, reflective values are also reflected from a senior cadet called "Abang" and junior cadets called "Adik." The word call is expected to strengthen solidarity and a high sense of brotherhood among cadets, in the same time, it is expected to minimize and even eliminate the impact of violence that often occurs in official schools (The interview result of Malahayati Merchant Marine Polytechnic of Aceh on July 7, 2019).

The implementation of religious character education is carried out by combining two approaches simultaneously: internal approach consisting of religious values instilled in student's self and external approach consisting character education monitored by Cadet Character Building Center of Aceh Merchant Marine Education (Interview result of a cadet of Malahayati Merchant Marine Polytechnic, Aceh on September 8, 2019). In its implementation, the approach is simultaneously combining three components of character education initiated by Thomas Lickona encompassing moral knowing, moral feeling, and moral action (Thomas Lickona, 2013) with Glock \& Stark' religious theory concept consisting of five religious elements: religious belief, religious practice, religious feeling, religious knowledge, dan religious effects (Glock \& Stark, 1970).

The field finding of the fifth diversity dimension, which the most dominantly appears, is the dimension of religious ritual and the dimension of the Religious Impact that is good enough. What looks weak in general is the dimension of religious appreciation and the dimension of religious science. The dimension of Religious Faith is suitable due to the form of religious Acehnese culture. According to this finding, it can be concluded that Cadets' religiosity has not been manifested ultimately, yet still partially.

The combination between character education and religious values will give moral consciousness for all people who are encouraged to do good and positive action, and the internal human self does not cause it. Otherwise, the encouragement to carry out the good things comes from inside the human self because they believe that inside the human self has the relationships among individuals so that the people who carry out the good things are reversed (Siswanto, 2013).

The observation result showed that religious values are manifested in the local wisdom and instilled in the cadet's self before carrying out the caregiving/education process. However, the stages are still in belief stages and showed religious ritual form. The caregiver realizes that this is one of the challenges to implement religious character education. The following is the interview result of the manager of the character education center.

"The activity of praying together that lead and managed by the cadets has run orderly. We usually invite Ustadz (Islamic Figure) to support the activities to carry out Islamic lectures adjusted to Islamic boarding culture. Besides, the call of Abang and Adik has usually been used in boarding life. Therefore, the seniority has been eliminated into respecting and cherishing while caregiving (Interview result of Character Building Center Manager on July 9, 2019). 
The character value of Order and Respect (the dimension of religious impact) appearing in the cadets' behavior is the words "Ready" and "Asking for Permission," which are always used for cadets' daily activities. It has been shown that cadets have implemented religious values that are symbolized by semi-military discipline.

\section{CONCLUSION}

The implementation of religious character education in Aceh Merchant Marine Education is one of the models of religious character education in The Ministry of Transportation of Republic Indonesia. The process of character education implementation applies a religious approach using Acehnese's local wisdom with a high religious spirit (Particularly for Islam). The process of character education implementation is carried out by the process of habituation and the condition of education environment through several aspects: figure, exemplary of the institution head/caregiver/coach/ senior cadets, behavior standard (cadet's code of conduct), local wisdom, and reflective study that are conducted through the activities of learning and training. Implementing religious character found five dimensions of religiosity that are incompletely appeared to manifest religious behavior, yet still partially. However, the dimension of religious ritual and the religious impact often appear in the cadets' daily behavior.

In contrast, religious appreciation and religious science are still weaker than other dimensions. That is good enough is the dimension of religious faith formed and encouraged by Acehnese local wisdom. The implementation of character education in Aceh Merchant Marine Education is believed to bear the cadets' profile of intelligent, professional, skilled, mentally, and physically healthy and good behavior (prospective transportation cadets).

\section{ACKNOWLEDGEMENTS}

Researchers thank State Islamic University Sunan Kalijaga Yogyakarta for funding this research.

\section{REFERENCES}

Akhtar, M., \& Saeed, M. (2021). Applying Activity Based Learning (ABL) in Improving Quality of Teaching at Secondary School Level. Pakistan Journal of Educational Research and Evaluation (PJERE), 3(2).

Deal, T. E., \& Peterson, K. D. (1999). Shaping school culture: The heart of leadership. Adolescence, 34(136), 802.

Efimova, O. I., Grinenko, A. V., Kalinina, N. V., Miroshkin, D. V., Bazhdanova, Y. V., Oshchepkov, A. A., \& Ivleva, S. A. (2019). Personality hardiness as a factor determining the interaction of a person with the environment (psychological and ecological aspects). Ecology, 28(107), 563-569. 
Farida, A. (2014). Pilar-Pilar Pembangunan Karakter Remaja. Bandung: Nuansa Cendekia.

Glock, C. Y., \& Stark, R. (1970). Religion and society in tension: a public. from the research program in the Sociology of Religion Survey Research Center, Univ. of Calif., Berkeley.

Hamdani, H. \& Saebani, A. B. (2013). Pendidikan Karakter Perspektif Islam, cet. ke-1, Bandung: CV. Pustaka Setia, 2013.

Hariyanti, T., \& Sudjito, S. (2018). Sustained character building through literature for college students in Indonesia. Jurnal Dinamika Hukum, 18(1), 109-122.

Ichsan (2011). Menata Kembali Pendidikan Karakter di Sekolah", Jurnal Al-Bidayah, Vol. 3, Nomor. 2.

Khwaja, A. Z., \& PaiVernekar, S. D. (2018). Human soul: A religious perspective.

Kovács, I. K., \& Borcsa, M. (2017). The relationship between anxiety, somatic symptoms, and Hardiness in adolescence. Romanian Journal of Psychology, 19(2).

Martin, G. \& Pear, J. (2015). Modifikasi Perilaku: Makna dan Penerapannya Edisi Kesepuluh, cet. ke-1, Yogyakarta: Pustaka Pelajar, 2015.

Pakta Integritas Resimen Taruna Periode Ke-2 Angkatan VI Politeknik Pelayaran Malahayati Aceh Tahun 2019.

Pedoman Pola Pengasuhan Taruna, Kementerian Perhubungan RI Badan Pengembangan SDM Perhubungan, Jakarta, 2018.

Peraturan Kepala Badan Pengembangan Sumber Daya Manusia Perhubungan, Nomor: PK. 2/ BSDMP-2018, tentang Pedoman Pengasuhan Taruna pada Lembaga Diklat Transportasi di Lingkungan Badan Pengembangan Sumber Daya Manusia Perhubungan.

Ping, O. W. (2020). An analysis of ecological and sustainability in religious perspective. Quantum Journal of Environmental Studies, 1 (1), 44-52.

Safitri, D. D. (2018). Managing school based on character building in the context of religious school culture (Case in Indonesia). Journal of Social Studies Education Research, 9(4), 274-294.

Safitri, D. D. (2018). Managing school based on character building in the context of religious school culture (Case in Indonesia). Journal of Social Studies Education Research, 9(4), 274-294.

Serdiuk, L., Danyliuk, I., Chykhantsova, O. (2019). "Psychological Factors of Secondary school Graduates' Hardiness", Social Welfare Interdisciplinary Approach.

Siswanto (2013). Pendidikan Karakter Berbasis Nilai-Nilai Religius, Jurnal Tadris, Vol. 8, Nomor. 1. Sutipyo, R. \& Latifah, A. "Prestasi Belajar Siswa Madrasah Aliyah Negeri (MAN) X Sleman Yogyakarta di Tinjau dari Dimensi Religiusitas", Nadwa: Jurnal Pendidikan Islam, Vol. 10, Nomor. 1, April 2016.

Tiwari, S. K. (2020). Identifying character education for research: discourse of relationship with culture, religion and other terms. Studies in Indian Place Names, 40(60), 917-933. 
Undang-Undang Republik Indonesia Nomor 20 Tahun 2003 Tentang Sistem Pendidikan Nasional.

Viola, M. M., Musso, P., Inguglia, C., \& Lo Coco, A. (2016). Psychological well-being and career indecision in emerging adulthood: The moderating role of Hardiness. The Career Development Quarterly, 64(4), 387-396.

Wardoyo, S. M. (2015). Pendidikan Karakter: Membangun Jatidiri Bangsa Menuju Generasi Emas 2045 Yang Religius. TADRIS: Jurnal Pendidikan Islam, 10(1), 90-103.

Wibowo, A., \& Purnama, S. (2013). Pendidikan karakter di perguruan tinggi: Membangun karakter ideal mahasiswa di perguruan tinggi. Pustaka Pelajar.

Zeer, E. F., Yugova, E. A., Karpova, N. P., \& Trubetskaya, O. V. (2016). Psychological Predictors of Human Hardiness Formation. International Journal of Environmental and Science Education, 11 (14), 7035-7044.

Dok. JawaPos.com, 2 Mei 2017.

Dok. JawaPos.com. 2 Mei 2017.

Dok. Tribun. Com.

Dok. Tribun. Com. 